\title{
ПРОБЛЕМЫ ЗАОЧНОГО ПРОИЗВОДСТВА В ГРАЖДАНСКОМ ПРОЦЕССЕ
}

\author{
(c) 2020 Лошкарев А.В. \\ доцент кафедры гражданского и арбитражного процесса \\ Самарский государственный экономический университет, Россия, Самара \\ E-mail: sseu.process2005@yandex.ru \\ (C) 2020 Руднева Ю. В. \\ старший преподаватель кафедры гражданского и арбитражного процесса \\ Самарский государственный экономический университет, Россия, Самара \\ E-mail: yuliarudneva66@mail.ru \\ (c) 2020 Турапина А.B. \\ студент направления «Юриспруденция» \\ Самарский государственный экономический университет, Россия, Самара \\ E-mail: alisya.turapina@mail.ru
}

\begin{abstract}
Раскрыты понятие и сущность заочного производства с точки зрения оптимизации судопроизводства при рассмотрении и разрешении гражданских дел на основании норм Гражданского процессуального кодекса РФ. Выделены преимущества существования данного института в процессе реализации правосудия в Российском государстве. Приведены особенности рассмотрения дела в отсутствие ответчика при наличии множественности субъектов на стороне истца. Раскрыты проблемные аспекты реализации заочного производства в правоприменительной практике РФ, предложены способы их нейтрализации.
\end{abstract}

Ключевые слова: гражданский процесс, заочное производство, заочное решение, процессуальные и материальные истцы, ответчик, нормативно - правовой акт, законодательство РФ

Современная редакция Гражданского процессуального кодекса РФ (далее - ГПК РФ) в отдельной 22 главе предусматривает наличие норм, отражающих процессуальные особенности осуществления заочного производства. Данный институт, введенный в структуру законодательства РФ с 1996 г., направлен на обеспечение ответственности сторон гражданского судопроизводства за свои действия с точки зрения предупреждения бюрократических издержек, которые могут возникнуть вследствие неявки ответчика в зал суда при рассмотрении гражданского дела. Институт заочного производства обеспечивает реализацию принципа состязательности сторон, установленного ст. 12 ГПК РФ [3], а также является гарантом доступа участников процесса к правосудию, которое, согласно п. 2 ст. 118 Конституции РФ [4], осуществляется в формах соответствующих конституционного, гражданского, административного и уголовного судопроизводства. Большинство ученых и практиков положительно оценивают введение и действие данного института с точки зрения оптимизации и сокращения временного лага при осуществлении гражданского процесса, не снижающего наличия юридических гарантий и обеспечения прав и свобод человека и гражданина [9]. Так, И.В.Решетникова отмечает, что по своему внутреннему содержанию институт заочного производства направлен на осуществление ускоренного правосудия, которое отражает компетенцию судов в деле предоставления всесторонней помощи в исследовании доказательств и эффективной интерпретации законодательства РФ при разрешении гражданских дел [5, с. 675]. А.В.Цихоцкий ссылается на рационализацию судопроизводства, достигаемую посредством введения данного вида института системы права, а В.М.Жуйков, критикуя в некотором роде правовые нормы в части действия заочного производства, отмечает, тем не менее, эффективность его применения на практике [7, с. 16-17].

Несмотря на то, что действующая редакция ГПК РФ достаточно содержательно освещает нормы, связанные с осуществлением заочного производства, тем не менее, в судебной практике возникают проблемы, обусловленные недостаточной разработанностью данного института 
и отсутствием спецификации и унификации в вопросах его толкования [8, с. 92].

Так, существуют несколько моделей осуществления заочного производства с позиции того, кто наделен правом на соответствующее производство. Это могут быть обе стороны, заочное производство может инициировать истец или это право не принадлежит ни одной из сторон. В российской правоприменительной практике действует вторая модель, допускающая осуществление судебного процесса в отсутствие ответчика, но не уточняя принципиальность присутствия истца при рассмотрении гражданского дела. Законодатель не устанавливает санкции в случае отсутствия истца, что ставит его в более выгодное положение по сравнению с фигурой ответчика, т.к. этим нарушается принцип равноправия сторон. В этом свете многие ученые ссылаются на необходимость закрепления в ГПК РФ норм, дисциплинирующих истца, вплоть до рассмотрения или закрытия дела в случае отсутствия уважительных обстоятельств у истца $[1$, c. 193].

Также среди проблемных моментов применения института заочного производства стоит отметить возможность рассмотрения дела в отсутствие ответчика при наличии множественности субъектов на стороне истца. В данном случае ГПК РФ регламентирует процесс принятия заочного решения при соучастии на стороне ответчика, не детализируя нормы, в соответствии с которыми допускается участие нескольких истцов на основании ст. 40 ГПК РФ [3] и дальнейшее принятие заочного решения. Участие нескольких истцов в заочном производстве является проблематичным ввиду того, что достижение консенсуса и компромисса в отношении согласия рассмотрения дела в отсутствие ответчика порой является трудоемким. В таком случае суд не имеет права рассматривать дело в заочном производстве, если один из истцов выступает против такого способа решения гражданского спора в отсутствие ответчика. В таком случае предлагается отложить рассмотрение дела до повторного судебного заседания и в случае повторной неявки ответчика следует учитывать вид соучастия [6, с. 140]. Так, при необходимом соучастии возможно рассмотрение дела и вынесение соответствующего решения, при факультативном целесообразным является выделение одного или нескольких видов исков в отдельное производство и на этой основе рассмотрение дела в чуть более позднем порядке [7, с. 17]. Соответственно, требование истца, который не возражает против судебного заседания в отсутствие ответчика, возможно представить к рассмотрению.

Особого внимания заслуживает практика, при которой разрешается спор с участием так называемых процессуальных истцов, которыми могут быть органы государственной и муниципальной власти, прокурор и т.д., и материальных истцов, интерес которых защищается в ходе возбуждения дела [1, с. 192]. Учитывая, что процессуальные истцы обладают полной совокупностью прав и обязанностей, определяющих их правовой статус, то в этом статусе они вправе инициировать заочное производство. В таком случае проблема возникает, если материальный истец не согласен на данную форму рассмотрения гражданского дела, а т.к. обязательность его присутствия ГПК РФ четко не регулирует, то возникает спорность положений о том, как должно быть предоставлено согласие истца на проведение заочного производства.

Производной проблемой в правоприменительной практике с участием процессуальных истцов может выступать подача иска в интересах неопределенного круга лиц. В данном случае гражданский спор устанавливает и защищает интересы многочисленной неопределенной группы лиц, состав которой в силу определённых обстоятельств сложно установить [2, с. 10]. В таком случае суд может интерпретировать деятельность ответчика как ущемляющую интересы данной группы и на таком основании признать ее противоправной. Поэтому при возникновении подобных случаев в судебной практике трудоемким является установление конкретного истца в материально-правовом смысле, что затрудняет выяснение мнения о возможности заочного производства и принятия судом соответствующего заочного решения.

В итоге с учетом вышесказанного можно заключить, что дефиниция заочного производства достаточно емко и содержательно раскрывается в действующих нормах ГПК РФ, давая представление об основаниях и порядке заочного производства, способах обжалования заочного решения суда и т.д. Однако в контексте института заочного производства представляется необходимым уточнение ряда правовых положений с тем, чтобы сделать процесс принятия заочных решений легитимным и унифицированным, со- 
ответствующим структуре нормативно - правовых актов РФ. Так, учитывая, что в контексте разрешения гражданского спора именно недобросовестность ответчика, игнорирующего повестку в суд, является фактором, существенно затягивающим судопроизводство, предлагается ввести положение о том, что именно отсутствие данного участника процесса является безусловной причиной рассмотрения дела в порядке заочного производства. Помимо прочего предлагается уточнить, что, по мнению законодателя, входит в перечень «уважительных причин», на которые, согласно ст. 242 ГПК РФ, может ссылаться ответчик в качестве оснований для отмены заочного решения. Дополнительно стоит отметить рациональность введения различных способов отмены заочного решения (например, обычного и упрощенного), варьирующихся в зависимости от сроков подачи соответствующего заявления со стороны ответчика с тем, чтобы рационализировать временные и материальные издержки, которые понесут субъекты гражданского процесса в случае повторного рассмотрения дела в суде. В совокупности отмеченные положения могут способствовать разрешению спорных моментов, возникающих в ходе судопроизводства, и в большей мере обосновывать эффективность правоприменения института заочного производства в современном правосудии РФ.

\section{Библиографический список}

1. Алейниченко В.Г.Некоторые проблемы правового регулирования заочного производства в гражданском процессе // Современная юриспруденция: актуальные вопросы, достижения и инновации: Сборник статей VII Международной научно-практической конференции. 2018. С. 191-193.

2. Брежнев И.Д., Горелов М.В. Вопросы заочного производства в гражданском процессе Российской Федерации // Студенческий вестник. 2019. № 19-2 (69). С. 9-11.

3. Гражданский процессуальный кодекс Российской Федерации: Федеральный закон от 14.11.2002 N $138-Ф 3$ (ред. от 02.12.2019) [Электронный ресурс] // URL: http://www.consultant.ru/document/cons_doc_LAW_39570/ (дата обращения 16.01.2020)

4. Конституция Российской Федерации: Принята всенародным голосованием 12.12.1993 (с учетом поправок, внесенных Законами РФ о поправках к Конституции РФ от 30.12.2008 N 6-ФКЗ, от 30.12.2008 N 7-ФК3, от 05.02.2014 N 2-ФКЗ, от 21.07.2014 N 11-ФК3) [Электронный ресурс] // URL: http://www.consultant.ru/ document/cons_doc_LAW_28399/(дата обращения 16.01.2020)

5. Маркосян А.В. Актуальные проблемы заочного производства в гражданском процессе Российской Федерации // Аллея науки. 2018. Т. 1. № 11 (27). С. 674-677.

6. Рахиев И.Х.Проблемы заочного производства в гражданском процессе Российской Федерации // Сфера знаний: научное взаимодействие в рамках образовательного процесса сборник научных трудов. Казань, 2018. С. $138-141$.

7. Сафонов М.О.Проблемы применения отдельных норм, регулирующих заочное производство в гражданском процессе // Законность и правопорядок: правосознание и правовая культура современного общества сборник материалов IV Международной научно-практической конференции. 2018. С. 14-18.

8. Скачков Н.С. проблемы заочного производства в гражданском процессе // Epomen. Global. 2019. № 1. C. 9197. 